\title{
Marine Biota and Biodiversity: A Sustainable Tourism Perspective
}

\author{
Ni Ketut Supasti Dharmawan ${ }^{1}$ and Made Sarjana ${ }^{2}$
}

\author{
${ }^{1}$ Civil Law Department, Faculty of Law, University of Udayana, Jalan Bali No.1, Denpasar, Bali, 80114, Ph./Fax: 0361 \\ 222666, Email: supasti_dharmawan@unud.ac.id \\ ${ }^{2}$ Civil Law Department, Faculty of Law, University of Udayana, Jalan Bali No.1, Denpasar, Bali, 80114, Ph./Fax: 0361 \\ 222666, Email: made_sarjana@yahoo.co.id
}

\begin{abstract}
Protection and conservation of marine biodiversity and their utilization based on sustainable environment, balance, and fairness play an important role in the context of sustainable tourism. The importance of protecting the availability of a healthy environment, which not only focuses on the present, but also a sustainable environment for future generations, is regulated under several provisions such as: Law of the Republic of Indonesia Number 27 Year 2007 on the Management of Coastal Areas and Small Islands, Law No. 32 of 2009 on the Environmental Protection and Management, Law No. 10 Year 2009 on Tourism, Law No. 5 Year 1990 on the Conservation of Biological Diversity and Ecosystems, the UN WTO Global Code of Ethics for Tourism, and the Convention on Biological Diversity. In order to protect and conserve marine biodiversity, it is considered relevant to use deep ecology approach in realizing the presence of marine biota and sustainable biodiversity for the entire ecosystem of life, including human life ecosystems in the development of tourism activities. States and all stakeholders have responsibility for the protection and conservation of biodiversity, including sustainable development of marine biota and its diversity for tourism activities.
\end{abstract}

Keywords: Biodiversity, Protection, Conservation, Responsibility, Sustainable Tourism

\section{INTRODUCTION}

Article 5 letter b of Law No. 10 Year 2009 on Tourism (Tourism Law) regulates linkages between tourism activities with Human Rights, especially based on the principle of individual right which one of the embodiment is the right to tourism [1]. However, such Tourism Law also regulates the rights aimed at the interests of the Third Generation of Human Rights, namely its collective nature or intended for the public. That can be seen in the Considering section letter (a) which determines that the nature, flora and ancient relics, relics of history, art and culture of the Indonesian nation constitute as resources and capitals of tourism development to increase the prosperity and welfare of the people as contained in Pancasila and the Preamble of the 1945 Constitution of the Republic of Indonesia. The resources and capitals of tourism development are very important to be maintained in order to establish a sustainable tourism. The Third Generation of Human Rights is also known as the Collective Rights or Peoples Rights [2]. Vasak (1990) suggested that the Third Generation of Human Rights is based on the principles of fraternity or solidarity while the First and Second
Generation of Human Rights are based on the principle of Individual Rights [3]. The fulfilment of the individual rights, such as the right to tourism supposes not making the rights of society as a whole to be reduced or neglected.

In order to fulfil the right of everyone to tourism, various tourism activities have been developed. In the end it is realized that tourism activities actually bring in foreign exchange and improve people's welfare and national development. Such development also aims to attract tourists to see the view of various rivers, mountains and the beautiful expanse of nature, to the tourist areas known as the underwater attractions. The underwater attractions present the beauty inside the sea. By diving for example, reefs and wide variety of species of fish and marine life will be seen and enjoyed by tourists. Indonesia's underwater tourism is widely known in international level. One of them is located in Tulamben, Karangasem of Bali Province. Tulamben is very popular because it is easy to reach the location, it has beautiful coral reefs and a variety of unique underwater creatures and the diversity of marine fish ranging from small ones like sea slugs, crabs, shrimps, jack fish, lion fish, garden eels, ghost pipe fish and pygmy seahorse until up to the big ones as sharks, molamola. Tulamben 
also supported by beatiful coral reefs that sticks to the walls of the cargo ship United USAT Liberty Glo sinking, who difers at a depth of 5 to 30 meters can enjoy the cracks ship united with marine life, coral reefs and variety of unique fishs which are sweaming around the venue. Moreover, Tulamben also offers a wide range of products related to the submarine tourism such as: offering many dive sites suitable for diving courses, fun dive and underwater photography.

The charm of the underwater flora and fauna as well as the beauty of diversity marine life on one hand can support enjoyment of the tourists. They enjoy, happy, and may more fresh after vacation surrounding the marine tourism areas. However, on the other hand the beauty of the underwater attractions and a variety of marine life and its biodiversity can be potentially endangered as a result of excessive and irresponsible exploitation of tourism activities. The sea with its biodiversity is losing its quality standards and function as a result of such overuse. The tourism sector is also criticized as the sector that is supported by the sea as its charm which in the end leaves another problem related to the sustainability of biodiversity including the ecosystems of underwater biota. In relation to this phenomenon, it is important to examine the responsibility of tourism sector related with protection and conservation to marine biota and its biodiversity. This study focuses on the study of: how is the regulation of marine biodiversity related to sustainable tourism? As well as who is responsible for the management of protection and conservation of the biodiversity? The purpose of this paper is to analyse the regulation of marine biodiversity, including in the national and international dimension as well as to analyse the responsibility of the state and relevant stakeholders in the management of protection and conservation of marine life biodiversity.

\section{RESEARCH METHOD}

This is a normative legal research which employs Statute, Conceptual, Comparative as well as Deep Ecology approaches. The examined legal materials are the primary and secondary legal materials. All legal materials were analysed in descriptive qualitative.

\section{RESULTS AND ANALYSIS}

\section{The Regulation on Marine Biodiversity Conservation in Tourism Activities}

Point (c) of the Consideration section of Tourism Law stipulates that tourism is an integral part of national development which is done in a systematic, integrated, sustainable and responsible ways while providing protection towards religious values, the living culture in society as well as sustainability and quality of the living environment. In relation to that, the appropriate stakeholders of tourism activities, especially the corporations that take advantage of the panoramic of underwater biota and biological diversity as part of its activities, together with the government and the state are responsible for realizing the tourism activities oriented to the sustainable management, conservation and environmental protection.

In improving sustainable tourism activities especially those which are supported by the charms of the sea, several provisions can be seen as relevant, namely: Article 5 paragraph (1), Article 20 paragraph (1) and Article 33 paragraph (3) of the 1945 Constitution of the Republic of Indonesia and Law No. 27 Year 2007 on the Management of Coastal Areas and Small Islands [4][5]. Coastal areas and small islands are part of the natural resources given by God Almighty which wealth is controlled by the state and must be preserved as well as its utilizations are for the greatest prosperity of the people, both for the present and future generations. In this regard, the exploitation of marine life and biodiversity in tourism activities shall refer to the Law No. 27 Year 2007.

Indonesia is famous as a country with its beautiful and extensive of coral reefs. Indonesian coral reef preservation plays a very important role both nationally, regionally and globally - a total area of the world's coral reefs reached $284.300 \mathrm{~km}^{2}$. Of the area, the Indonesian water is the one who has the most extensive coral reef, which is $51.020 \mathrm{~km}^{2}$ (18\% of the world's coral reefs) followed by Australia $\left(48.000 \mathrm{~km}^{2}\right.$ ) and the Philippines $\left(25.000 \mathrm{~km}^{2}\right)$. Because of it is extensive and its diversity of species is very high, Indonesia is mentioned by the oceanographers as the centre of global coral triangle.

Although Indonesia has beautiful and extensive coral reefs, however it cannot be denied that the reefs in Indonesian water are suffering serious destruction and therefore requires attention from all parties. The prohibition against malicious activity on coral reefs stipulated in Article 35 of the Law No. 27 Year 2007 which basically sets the prohibitions on taking coral reefs in the conservation areas, using explosives, toxic substances, and/or other substances that destroy coral reef ecosystems and taking equipment, means, and other methods that destroy coral reef ecosystems. The provision of Article 1 paragraph (3) of Law No. 32 of 2009 on the Environmental Protection and Management also regulates sustainable development as a conscious and planned effort that combines aspects of environmental, social, and economic development strategies to ensure the environmental integrity and safety, capability, prosperity and quality of life of present and future generations [6]. With regard to the achievement of tourism sustainable development, there are three important pillars that must be considered and maintained in harmony, namely: the balance of economy, environmental and social coupled with the pillar of climate change. The issue of climate change has an influence both directly and indirectly to the development of economy and social culture [7].

The regulation on biodiversity can also be found in Article 2 of the UN Convention on Biological Diversity 1992 (CBD): "Biological diversity" means the variability among living organism from all sources including, inter alia, terrestrial, marine and other aquatic ecosystems and the ecological complexes of which they are part: this includes diversity within species, between species and of ecosystems [8]. Based on the definition set out in Article 
2 of the CBD, Kundis Robin Craig (2005) identified three (3) important elements in regulating the definition of biodiversity, namely: genetic diversity, species diversity and ecosystem diversity [9]. Besides that, such Article 2 also stresses that biodiversity including the study of biodiversity in the terrestrial, marine and other aquatic ecosystems and the ecological complexes which they are part (other aquatic ecosystems). Indonesia as one of the countries that ratified the CBD through Law No. 5 Year 1994 stipulates that "biodiversity" is diversity among living organisms from all sources, including, terrestrial, marine and other aquatic ecosystems as well as the ecological complexes that are part of its diversity, this includes diversity within species, between species and of ecosystems. The existence of biodiversity both in the marine, terrestrial and other aquatic ecosystems are very important to be protected and preserved because its existence has a very large contribution to the quality of human life.

The United Nations Environmental Program (UNEP), stressed that the loss of biodiversity threatens our food supplier, opportunities for recreation and tourism, as well as sources of wood, medicines and energy [10]. To emphasize the importance of preserving the existence of biodiversity, Indonesia as a member state, in the letter (b) of the Considering section stipulates that The existence and sustainability of biodiversity includes ecosystems, species and genetic includes animals, plants and microorganisms need to be guaranteed for life. Indeed the existence of biodiversity, including marine life is very helpful. One of the benefits is to support food chains and nets. Biodiversity supports ecosystem stability, namely: food chains and nets are in balance, the balance of species composition, as well as the more complex components of the ecosystem, the more efficiently the ecosystem will last [11]. In order to support policies and agreements to the CBD, a number of protocols have been issued in international level such as: the Cartegena Protocol on Biosafety to the Convention on Biological Diversity, and the Nagoya Protocol on Access to genetic Resources and the Fair and Equitable Sharing of Benefits Arising from their Utilization to the Convention on Biological Diversity (Nagoya Protocol) [12].

Regulation on the protection and conservation of biodiversity including marine life is very important to be enforced, especially in the context of sustainable ecosystem. It is because sustainable ecosystems always put balance and harmony, interdependence between humans and the natural surroundings based on the deep ecology with ecosophy approach and its relevance with human rights. The utilization of the current biodiversity resources has relevance to ensure sustainable environment included therein in order sustainable tourism. Article 1 Paragraph (2) and Paragraph (3) of Law No. 5 Year 1990 on the Conservation of Biological Diversity and Ecosystems regulates matter on the management of natural resources which utilization is wisely used to ensure a balance supply while maintaining and improving the quality of its biodiversity and values, as well as the existence of natural resource ecosystems [13]. It is a system of interrelationships between elements in nature, both living and non-living, which are mutually dependent and influencing.

Protection and conservation of marine biota constitute an integral part of the marine protection in a broader context, as can be seen from the Law No. 32 Year 2014 on Marine (Marine Law). Marine conservation cannot be separated by the activities or efforts towards the sea. Indonesian marine law also emphasized the importance of the underlying management and utilization of marine resources based on the notion of blue economy. Based on the elucidation of Article 14 Paragraph 1 of Marine Law, it is noted that "blue economy" is an approach to improve the sustainable marine management and conservation as well as coastal resources and their ecosystems in order to realize economic growth with the principles among others: community involvement, resource efficiency, waste minimization, and multiple revenue. Gunter Paulli, originator of the first blue economy concept which criticized the weakness of the concept of the green economy, argues that the blue economy is the economic development based on marine aspects, but not only exploit marine resources but also the maintain and protect marine ecosystems. This concept is a form of marine industrialization and fisheries policies which is based on modernization. In other words, this blue economy accelerates economic growth by exploiting the marine and fisheries potential [14].

The blue economy concept is very relevant to be applied in marine management in Indonesia, including in the biodiversity and marine biota protection and conservation. It is because as it is known, Indonesia is the largest archipelago in the world with $95.181 \mathrm{~km}$ long of coastline, and with the sea area of 5.4 million $\mathrm{km}^{2}$. Indonesia has huge potential marine resources, including its biodiversity and the largest non-living marine and aquaculture of the world. In connection to Indonesia's marine potential, the government's role is needed to develop the marine-based economic sectors. One idea that can be applied to accelerate the development of marine economy of Indonesia is to use the concept of the blue economy (Ibid.).

\section{Stakeholder's Responsibilities in Protecting Marine Biota and Biodiversity}

The continuation existence of biodiversity and ecosystems, including marine biota as has been stated previously, is very beneficial to the surrounding environments, including human life. The extinction of one species of biodiversity will disturb other ecosystems, therefore, in a variety of regulations that intersect with the environment including marine environment, it is easily to be found provisions on the protection and conservation which are able to guarantee the sustainability of the ecosystem for the benefit of future generation. In other words, sustainable development, sustainable environment and sustainable tourism aimed not only to the present life, but also ensure its survival for future generation. Holistically with the principle of Deep Ecology approach, in order to ensure the sustainability of biodiversity and the whole ecosystem, the frontline responsibility is on the shoulders of the state. The provision on it can be seen 
through the general elucidation of Law No. 32 Year 2009 which regulates that a good and health living environment constitutes as human rights and constitutional rights of every citizen of Indonesia [15]. Therefore, the state, the government and all stakeholders are obliged to carry out sustainable environmental protection and management therefore environmental still being as source of life and support of the Indonesian people as well as other living things.

Article 235 of the United Nations Convention on the Law of the Sea (hereinafter referred to as UNCLOS) of 1982 determines that each state is responsible for fulfilling international obligations concerning the protection and preservation of the marine environment. Each state should ensure the availability of effort in their law system on how to obtain compensation promptly and adequately with regard to the damage caused by natural persons or legal entities under its jurisdiction. Each state should cooperate in implementing the international law governing the responsibility and liability indemnity for compensation for losses due to pollution of the marine environment, as well as the payment procedure. Indonesia is one of the states that have ratified the UNCLOS 1982. Article 25 in conjunction with Article 26 of Marine Law stipulates that in order to utilize and manage the marine industry (one of which industrial biotechnology), the Central Government and the Local Government are responsible to develop and enhance the marine biotechnology industry which is done by utilizing the potential of biodiversity aimed to transform and prevent the extinction of marine life as a result of exploration excess, develop environmentally friendly technology at every marine industry, and develop marine resource management system on an on-going basis. Besides that, all relevent stakeholders in the utilization of biological diversity are responsible together with the government to ensure the protection and implementation of conservation and to prevent environmental pollution so it is not damaging or interfering with the survival natural resources biodiversity including marine biota. Provisions governing the responsibilities of stakeholders can be seen in: Article 23-26 of Tourism Law, as well as Article 3 the UN WTO [16].

\section{CONCLUSION}

1. Regulation on the protection and conservation of the biodiversity and marine life is set out in a range of conditions both internationally as the United Nations Convention on Biological Diversity in 1992 and its Protocols or nationally which basically stipulates that biodiversity is including diversity among living organisms from all sources, including, terrestrial, marine and other aquatic ecosystems as well as ecological complexes that are part of its diversity, this includes diversity within species, between species and ecosystems. Conservation activities are very important to be maintained, protected and carried out its presence is very beneficial to the quality of human life, especially in the context of sustainable human life in the human rights dimension, including sustainable tourism.
2. The parties responsible for the law enforcement in relation to the protection of biodiversity and marine life in the context of sustainable tourism are the state and all stakeholders including corporations in tourism sector associated by various laws such as the CBD, the UN WTO, Law on Environmental Protection and Management, Tourism Law and Marine Law.

Suggestion

1. Government is expected to make Action Plan with regard to the protection and conservation of biodiversity, particularly marine biota and disseminate it in a sustainable manner, especially to the relevant stakeholders engaged in tourism activities. Therefore, the existence of biodiversity of marine life will be save and continue to be useful in the context of the fulfilment of human rights towards ecosystem resources for the future generations.

2. Governments, law enforcement officers and academics are expected to disseminate the responsibilities of all stakeholders to jointly enforce the law both in the local, national and international levels with regard to the protection and conservation of biodiversity, in particular, marine biota.

\section{ACKNOWLEDGMENT}

Through this article, we would like to deliver our sincere gratitude to the Dean of the Faculty of Law, University of Udayana, Head Master of Notary and $L P P M$ of University of Udayana for the financial and moral supports therefore this HUPS research and its publication can be held on time.

\section{REFERENCES}

[1] Law No. 10 Year 2009 on Tourism

[2] Freedman, R. 2013. Third generation Rights: Is There room for Hybrid Constructs Within International Human rights Law, Cambridge Journal of International and Comparative Law (2)4:935.

[3] Bülent. A. 2004. Rethinking Third Generation Human Rights, Ankara Law Review Vol. 1, No. 1. Summer 2004.

[4] The 1945 Constitution of the Republic of Indonesia.

[5] Law No. 27 Year 2007 on the Management of Coastal Areas and Small Islands

[6] Law No. 32 of 2009 on the Environmental Protection and Management.

[7] Chatarayamontri, N. 2009. Sustainable Tourism And The Law: Coping wih Climate Change (Dissertation \& Theses), Paper 6, Available: http://digitalcommons.pace.edu /lawdissertations/6.

[8] The UN Convention on Biological Diversity.

[9] Craig, R. K. 2005. Protecting International Marine Biodiversity: International Treaties and National Systems of Marine Protected Areas, Journal of Land Use Vol.20, No.2., Spring 2005.

[10] UNEP (Secretariat of the Convention on Biological Diversity). 2000. Sustaining life on Earth How the Convention on Biological Diversity Promotes Nature and Human Well-Being. 
[11] Arthana, I.W. 2016. Tantangan dan Solusi Perlindungan dan Pemanfaatan Berkelanjutan Keanekaragaman Hayati di Bali, makalah dalam Konsultasi Publik Diplomasi Indonesia menuju Konferensi Negara Pihak ke-13 Konvensi PBB Keanekaragaman Hayati, 16 Juni 2016.

[12] Arsika, I M.B. 2011. Implikasi Ratifikasi Dan implementasi Atas Konvensi PBB mengenai Keanekaragaman Hayati, Makalah dalam Konsultasi Publik Diplomasi Indonesia menuju Konferensi Pihak ke-13, 16 Juni 2016.
[13] Law No. 5 Year 1990 on the Conservation of Biological Diversity and Ecosystems.

[14] Satria, A. E. 2014. Ekonomi Biru Sebagai Prinsip Ekonomi Berkelanjutan di Indonesia, Available: http://www.kompasiana.com/andikaekasatria/ekono mi-biru-sebagai-prinsip-ekonomi-berkelanjutan-diindonesia_54f4b808745513a32b6c8d3b

[15] Law No. 32 Year 2014 on Marine

[16] The UN WTO Global Code of Ethics for Tourism. 